\title{
Impact of 'Mgnregs' on Income and Employment of Small Farmers and Labourers: A Comparative Study in Telangana State, India
}

\author{
D. Kumara Swamy*, C.V. Hanumanthaiah, P. Parthasarathy Rao, \\ K. Suhasini and V.V. Narendranath
}

Department of Agricultural Economics, College of Agriculture, Professor Jayashankar Telangana State Agricultural University, Rajendranagar, Hyderabad - 500030, India

*Corresponding author

\begin{abstract}
A B S T R A C T
A study was conducted in former Karimnagar and Medak districts of Telangana state to quantify the impact of Mahatma Gandhi National Rural Employment Guarantee Scheme (MGNREGS) on small farmers and agricultural labourers by comparing the beneficiaries

Keywords

MGNREGS,

Highest

Expenditure

Mandals (HEMs),

Lowest Expenditure

Mandals (LEMs),

Beneficiaries,

Income transition and Wage rate).

Article Info

Accepted:

17 June 2018

Available Online:

10 July 2018

with non beneficiaries. Results revealed that per farm income of non beneficiary group farmers in Highest Expenditure Mandals (HEMs) of Karimnagar was highest i.e. $\square .42120$. Per family average income from livestock sources was highest for beneficiaries of HEMs of Medak i.e $\square .4981$ and lowest for beneficiaries of Lowest Expenditure Mandals (LEMs) of Karimnagar i.e $\square .3025$. The agricultural labourers livestock income was highest for beneficiaries of HEMs of Medak i.e. $\square .5531$ and lowest for non beneficiaries of HEMs of Medak i.e $\square .1025$. Income transition was clearly seen and majority of labourers crossed poverty line in HEMs of Karimnagar. Beneficiary labourers in HEMs of Medak got highest number of employment days in the study year (199.75 days) and non beneficiary labourers in LEMs of Medak got lowest number of employment days (131.62 days) where as non beneficiary farmers in LEMs of Karimnagar got highest number of employment days (193.31 days) and beneficiary farmers in LEMs of Medak got lowest number of employment days (145.06 days). Major discriminator between beneficiary and non beneficiary farmers were total annual income (172.43\%), expenditure on hired human labour (80.59\%), income from livestock (7.29\%) and age of labourer (4.8\%). Major discriminating factors between beneficiaries and non beneficiary agricultural labourers were total annual income $(50.70 \%)$, social class $(45.15 \%)$, total employment days got $(37.24 \%)$, family size $(32.63 \%)$ and average wage rate $(11.84 \%)$ respectively and $97.37 \%$ and $92.8 \%$ variation found in total annual income for farmers and labourers.
\end{abstract}

\section{Introduction}

Though Mahatma Gandhi National Rural Employment Guarantee Scheme (MGNREGS) was initiated with a specific goal of providing minimum guarantee wage rate, employment days, local employment etc., its ultimate outcome on people is varied from place to place and time to time. Few studies have revealed a clear positive impact (Akthar, 
2009), a rise in real wages and number of annual employment days available (Alha and Yonzon, 2011) and few other studies revealed that MGNREGS beneficiaries got low incomes than non beneficiaries (Ahuja et al, 2011) and there was a significant difference in income levels in areas where scheme was implemented partially compared to full pledge implemented areas (Reddy et al, 2016). In few studies, actual incomes and total number of annual employment days were also calculated.

The present study was aimed at the estimation of total annual incomes of beneficiary and non beneficiary famers and beneficiary and non beneficiary labourers of MGNREGS, total number of employment days available to these groups, their income transition patterns, and significant factors differentiating these two groups (beneficiaries and non beneficiaries) of farmers and labourers in selected mandals of Karimnagar and Medak districts of Telangana state during 2013-14 year.

\section{Objectives}

Two estimate the employment pattern of sample MGNREGS beneficiary and non beneficiary farmers and labourers in the study area. Two estimate the income earning pattern of sample MGNREGS beneficiary and non beneficiary farmers and labourers in the study area.

\section{Materials and Methods}

The present study was conducted in Karimnagar and Medak districts of Telangana state (formerly part of Andhra Pradesh) during 2013-14. In each district, two mandals were selected purposively where comparatively highest amount of money was spent for MGNREGS by the government and two mandals where lowest amount of money was spent.
From each selected mandal, two villages were selected randomly and from each selected village, eight beneficiaries and eight non beneficiaries were selected of which 50\% (four) were small famers and 50\% (four) were labourers. Thus it made 64 small farmers and 64 labourers from each district and finally it made a sample size of 256 respondents.

Data regarding net incomes and savings thereafter were collected from sample farmers and labourers as per the objectives of the study by interview method. The data were obtained by a pretested questionnaire specially designed for the purpose. The data collected thus were analyzed using different tabular and statistical techniques, interpreted and drawn conclusions (Table 1).

\section{Results and Discussion}

Impact of MGNREGS on income patterns of the beneficiaries and non beneficiaries of the scheme

Income obtained by farmers as MGNREGS beneficiaries and as non beneficiaries is estimated in the study area (Fig. 1-6).

Income of the sample farmers from agriculture

In both HEMs and LEMs, the average per farm and per hectare incomes of the non beneficiaries was found to be more than beneficiaries in both Karimnagar and Medak districts (Table 2).

The per farm income of the non beneficiaries in HEMs of Karimnagar was more than the beneficiaries (34.28 percent), while in LEMs, the difference between beneficiaries and non beneficiaries' was 12.07 percent.

In HEMs of Medak district non beneficiaries per farm income was 1.70 percent more than 
beneficiaries, while in LEMs the difference was 64.95 percent. In Karimnagar district, the average per hectare income of the non beneficiaries in HEMs was 38.11 percent more than beneficiaries and in LEMs, it was 36.19 percent. The same trend was noticed in Medak district also.

The difference in incomes between beneficiaries and non beneficiaries were high in both HEMs and LEMs in Karimnagar district and it was low when compared to Medak district. In Medak district, the differences between HEMs and LEMs were very large in income realization. This may be due to the cropping pattern prevailed in HEMs of Medak such as sugarcane, onion, zinger and redgram crops in addition to rice.

Both per farm and per hectare annual incomes of beneficiary farmers were less than the non beneficiaries. This may be due to non beneficiaries may have other good alternative income sources or beneficiaries satisfied with the less number of days of work available in a year. However, it was confirmed that non beneficiaries' average annual income was more than MGNRGES beneficiaries.

The results were appear to be quiet logical as the beneficiary MGNREGS farmers made less agricultural income and less than the non beneficiaries and however it was found that the beneficiary groups under HEMs and LEMs in both Karimnagar and Medak districts competed with non beneficiaries groups in income realization. This phenomenon may be attributed to more reasonable conclusion that the MGNREGS impact on beneficiaries was significant as the results show that beneficiary groups' incomes incurred to an extent on par with non beneficiaries (Jha 2011).

\section{Income pattern from livestock}

Data related to livestock income on per family and per animal basis (Table 2) indicated that the per family income of sample farmers in both the districts, beneficiaries in HEMs obtained higher income from livestock than non beneficiaries with 12.45 percent and 44.90, but in LEMs non beneficiaries income from livestock was more than beneficiaries with 30.16 percent and 45.41 percent in both Karimnagar and Medak respectively.

This may be because of the reason that in HEMs, more days of work available under MGNREGS and so got more leisure time to take care of their own livestock rearing activities effectively or may due to availability of increased amount of fodder and other required greenery with the implementation of MGNREGS which helped in soil conservation and increased water table with higher expenditure on the scheme.

The agricultural beneficiary labourers per family income from livestock source in Karimnagar district in both HEMs and LEMs, the income from livestock for beneficiaries was less than the non beneficiaries with 10.89 percent and 22.10 percent respectively. But in Medak district, it was different as the beneficiaries income from livestock was more than non beneficiaries in both HEMs (39.63 per cent) and LEMs (51.77 per cent) respectively.

The per animal income of beneficiary sample farmers, in all the study area was lower than non beneficiaries with 26.36, 90.24, 42.94 and 127.20 per cent for HEMs of Karimnagar, LEMs of Karimnagar, HEMs of Medak and LEMs of Medak respectively. The per animal income of agricultural labourers in both HEMs and LEMs of Karimnagar district was more than the beneficiaries with 10.89 per cent and 30.82 per cent respectively, but in Medak district, in both HEMs and LEMs, beneficiaries per animal income was more than non beneficiaries with 169.81 per cent and 140.31 per cent respectively (Table 3 ). 
Hence, it is clear that in HEMs of both the districts, beneficiary farmers' livestock income was higher than non beneficiary farmers while in LEMs, non beneficiary farmers' livestock income was higher than beneficiaries and there was no much difference observed between beneficiaries and non beneficiaries. Interestingly per animal incomes of the non beneficiary sample farmers was highest in the study area than the beneficiaries. In the case of Karimnagar district, the beneficiary agricultural labourers in both highest and lowest expenditure mandals on per family basis realized less income when compared to non beneficiaries. In the case of Medak district, the beneficiary agricultural labours realized higher incomes when compared to non beneficiaries. These two contradicting results were logical as beneficiary agricultural labours in Karimnagar district, though earned low livestock income; their incomes were on par with non beneficiaries while in Medak district the beneficiaries in both highest and lowest expenditure mandals have earned high levels of income on livestock compared to non beneficiaries.

Livestock income depends on the availability of fodder, management and willingness to rear. So it can be said that the Medak agricultural labour are more interested in livestock rearing which fetched them more income. The per animal data has indicated a different trend in sample farmers and agricultural labourers. The striking feature on per animal basis in Medak district in both highest and LEMs was that the beneficiaries' incomes were higher than the non beneficiaries.

\section{Contribution of farm wages and nonfarm wages}

Small farmers beneficiary have realized more farm wage incomes of $\square 3672$ when compared to MGNREGS farm wage income ( $\square$ 3339) in the total annual average wage income in HEMs while in LEMs the same trend was noticed in the MGNREGS farm wage income was more ( $\square$ 3482) compared to nonfarm wage small farmer group ( $\square$ 2767).

Agricultural labourers farm wage incomes were more ( $\square$ 2244) when compared to nonfarm wage incomes ( $\square$ 2034) in HEMs of Karimnagar. Similar trend was observed in LEMs of Karimnagar district. In all the study areas of Medak district, the same trend was noticed in case of both farmers and agricultural labourers.

In agricultural labourers group, the income from farm wages accounted to 73.23 per cent and 75.05 per cent of total income in Karimnagar and Medak.

\section{Share of MGNREGS income in total income}

The small farmers in HEM of Karimnagar district have realized 25 percent of the incomes from MGNREGS source while in LEMs the incomes were on par with HEMs with 25 percent again in Karimnagar district. Table 4 depicts the share of income from MGNREGS to the total income for the sample beneficiaries in both the districts.

In Medak district, the HEMs indicated only 11 percent with respect to small farmers groups while in LEMs incomes were 24 percent of the incomes of small farmers.

The agricultural laborers' data in HEMs of Karimnagar district indicated that the contribution of MGNREGS source was 72 percent to total incomes while it was 50 percent in LEMs. In Medak district interestingly the LEMs pertaining to agricultural labourer indicated that NREGS contribution was 61 percent while that of 
HEMs (49 percent). Thus, it can be concluded that both small farmers and agricultural labourers have realized good percentage of incomes which ranged between 11-25 percent in small farmers groups while it was in the range of 49-72 percent in agricultural labourers to total incomes.

Total annual income patterns of MGNREGS beneficiary versus non beneficiaries

\section{a. Small farmers}

Except in HEMs of Medak district, in all other cases non beneficiaries' average annual income is more than the beneficiaries. In HEMs of Karimnagar, beneficiaries' total annual income is 27.95 per cent more than non beneficiaries and LEMs, beneficiaries annual income is 29.16 per cent more than non beneficiaries. In HEMs of Medak, beneficiaries total annual income is 60.15 per cent more than non beneficiaries where as in LEMs of Medak, non beneficiaries got more income than beneficiaries by 4.76 per cent.

\section{b. Agricultural labourers}

In case of agricultural labours, in all the areas of two districts, except in highest expenditure mandals of Karimnagar district the average annual income of beneficiary labourers is more than non beneficiaries (Akhtar and Azeez 2012). In HEMs of Karimnagar, non beneficiaries got 4.82 per cent more income than beneficiaries and LEMs, beneficiary labourers got 7.07 per cent more income than non beneficiaries. In Medak, beneficiary labourers on HEMs got 40.35 per cent more income than non beneficiaries whereas in LEMs, beneficiaries got 13.90 per cent more income than non beneficiaries .

It was clear from the above discussion that in all the areas, farmers income is higher than labourers and this gap is very high in highest expenditure mandals of Medak where commercial crops are grown at large scale compared to all other areas where food crops are predominantly cultivated.

\section{Income mobility pattern}

The mobility or shift of the MGNREGS beneficiaries with respect to income levels is presented in the form of income transition matrices or stochastic matrices

\section{i) Income mobility of sample farmers}

In Karimnagar, it was observed that majority (31.25 per cent) of farmers were moved from Rs. $40001-60000$ income group to Rs. 60001-80000 income group in HEMs and in LEMs a majority (25 per cent) were shifted from Rs. 20001 - 40000 income group to Rs. 40001 - 60000 income group and another 25 per cent of farmers moved from Rs. $<20000$ income group to Rs. 20001 - 40000 income group.

In Medak, a majority (31.25 per cent) of farmers in HEMs remained in the same income group of Rs. < 50000 income group inspite of additional income from MGNREGS. In LEMs, majority (37.5 per cent) were moved from a lower income group of Rs. $<20000$ to Rs. $20001-40000$ income group.

\section{ii) Income mobility of agricultural labourers}

In Karimnagar, majority of agricultural labourers (62.5 per cent) in HEMs moved from Rs. < 10000 income group to Rs. 10001 - 20000 income group and LEMs, a majority (37.5 per cent) moved from Rs. 10001- 20000 income group to Rs. 20001-30000 income group.

In Medak, a majority (25 per cent) of agricultural labourers in HEMs moved from Rs. < 10000 income group to Rs. 10001- 
20000 income group and another 25 per cent of labourers moved from two steps i.e to Rs. 20001 - 30000 income group and LEMs, a majority (56.25 per cent) moved from Rs. < 10000 income group to Rs. 10001-20000 income group.

Regarding crossing poverty line, all the sample farmers were found to be above poverty line even without MGNREGS income and in case of agricultural labourers about 81.25 per cent, 25 percent, 31.25 per cent and 75 per cent of beneficiary labourers crossed poverty line in HEMs of Karimnagar, in LEMs of Karimnagar, in HEMs of Medak and in LEMs of Medak respectively (Thadathil and Mohandas (2011)).

Impact of MGNREGS on employment of sample beneficiaries and non beneficiaries

The MGNREGS programme main aim is to provide man days of work on different areas like farm, non farm and construction work for both small farmers and agricultural labourers. Accordingly the data was collected, analyzed and presented in Table 5 .

In HEMs of Karimnagar district, small farmers were benefitted with 104.87 man days in farm work followed by nonfarm (40.25 man days) and construction work (30.18 man days) while in LEMs, the farm work man days were 100 days and highest among all other work man days. However, the farm work man days were relatively high by 15 days in HEMs of Karimnagar district while there was not much difference in LEMs. The agricultural labourers farm work man days in HEMs of Karimnagar district were with 61.37 man days followed by non farm work days 54 and construction work 48 days.

The same trend was noticed in LEMs. The interesting feature was that with respect to farm work days for both small farmers and agricultural labourers in HEMs and LEMs of Karimnagar district were highest in relative terms compared to the MGNREGS works.

Thus, it can be concluded that the government intervention of MGNREGS implementation has fulfilled as it catered the specific needs of rural population in providing farm work that helped agricultural development which reflected in terms of more man days to farm work on relative terms of other MGNREGS works (Alha and Yonzon 2011).

Significant difference between beneficiaries and non beneficiaries in case of Total annual employment days

Using the paired 2 sample $\mathrm{t}$ - test, it was found that for both farmers and labourers in all the areas of two districts, there was no significant difference between the beneficiaries and non beneficiaries in case of total number of employment days. Hence, we accept the null hypothesis (there is no much difference between the beneficiary and non beneficiaries' total number of employment days).

However, though there was no significant between beneficiaries and non beneficiaries, a clear absolute difference was found.

\section{Factors affecting the total annual incomes}

\section{i) Farmers}

To study the influence of various factors effecting on total annual incomes of beneficiary and non beneficiary farmers of highest and lowest expenditure mandals of Karimnagar and Medak districts, multiple regression analysis was carried out after confirming that there was no multicolinearity among the identified variables. 
Table.1 Sample villages selection procedure

\begin{tabular}{|c|c|c|c|c|c|c|c|c|c|c|c|c|c|c|c|c|}
\hline Dist & \multicolumn{8}{|c|}{ KARIMNAGAR } & \multicolumn{8}{|c|}{ MEDAK } \\
\hline Criteria & \multicolumn{4}{|c|}{$\begin{array}{l}\text { Highest Expenditure } \\
\text { Mandals (HEMs) }\end{array}$} & \multicolumn{4}{|c|}{$\begin{array}{l}\text { Lowest Expenditure } \\
\text { Mandals (LEMs) }\end{array}$} & \multicolumn{4}{|c|}{$\begin{array}{l}\text { Highest Expenditure } \\
\text { Mandals (HEMs) }\end{array}$} & \multicolumn{4}{|c|}{$\begin{array}{l}\text { Lowest Exper } \\
\text { Mandals (LEMs) }\end{array}$} \\
\hline Mandal & \multicolumn{2}{|c|}{ Mutharam } & \multicolumn{2}{|c|}{ Kataram } & \multicolumn{2}{|c|}{ Eligaid } & \multicolumn{2}{|c|}{ Mallial } & \multicolumn{2}{|c|}{ Narayankhed } & \multicolumn{2}{|c|}{ Raikode } & \multicolumn{2}{|c|}{$\begin{array}{l}\text { Shankaram } \\
\text { pet (A) }\end{array}$} & \multicolumn{2}{|c|}{$\begin{array}{l}\text { Shankaram } \\
\operatorname{pet}(\mathrm{R})\end{array}$} \\
\hline$\stackrel{\substack{\infty \\
ٍ}}{=}$ & 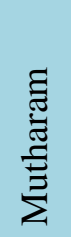 & 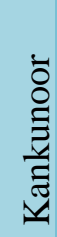 & 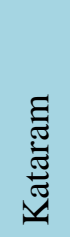 & & 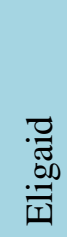 & 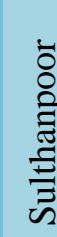 & 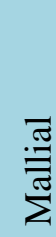 & $\frac{\underset{\pi}{\tilde{J}}}{\underset{\Xi}{\tilde{Z}}}$ & 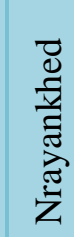 & $\begin{array}{l}\frac{\pi}{0} \\
\frac{\pi}{0} \\
\frac{0}{2} \\
\frac{0}{4}\end{array}$ & 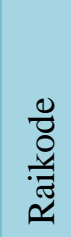 & 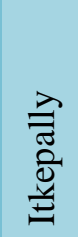 & 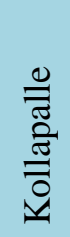 & 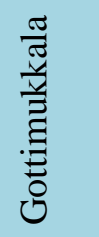 & $\stackrel{\Xi}{\Xi}$ & $\frac{\Xi}{\bar{Z}}$ \\
\hline
\end{tabular}

Table.2 Average annual income of the sample farmers from agricultural crops (Rs/year)

\begin{tabular}{|l|c|c|c|c|c|c|c|c|}
\hline \multicolumn{1}{|c|}{ S.No } & \multicolumn{4}{|c|}{ Karimnagar } & \multicolumn{4}{c|}{ Medak } \\
\hline \multirow{2}{*}{ Particulars } & \multicolumn{2}{|c|}{ HEMs } & \multicolumn{2}{c|}{ LEMs } & \multicolumn{2}{c|}{ HEMs } & \multicolumn{2}{c|}{ LEMs } \\
\cline { 2 - 10 } & B & NB & B & NB & B & NB & B & NB \\
\hline Per farm & 31366.99 & 42120.05 & 26151.46 & 29308.96 & 96779.22 & 98431.78 & 32130.66 & 53000.18 \\
\hline Per hectare & 17393.43 & 24023.06 & 13057.35 & 17783.36 & 58417.41 & 61382.95 & 21314.48 & 36715.38 \\
\hline
\end{tabular}

(B = Beneficiary, NB = Non Beneficiary $)$

Table.3 Average annual income from livestock for sample respondents in the study area (in Rs/year)

\begin{tabular}{|c|c|c|c|c|c|c|c|c|c|c|}
\hline \multirow[t]{3}{*}{ S.No } & \multirow{3}{*}{\multicolumn{2}{|c|}{ Group }} & \multicolumn{4}{|c|}{ Karimnagar } & \multicolumn{4}{|c|}{ Medak } \\
\hline & & & \multicolumn{2}{|c|}{ HEMs } & \multicolumn{2}{|c|}{ LEMs } & \multicolumn{2}{|c|}{ HEMs } & \multicolumn{2}{|c|}{ LEMs } \\
\hline & & & B & NB & B & NB & B & NB & B & NB \\
\hline \multirow[t]{2}{*}{1} & \multirow[t]{2}{*}{$\begin{array}{l}\text { Per } \\
\text { family }\end{array}$} & $\begin{array}{l}\text { Sample } \\
\text { farmers }\end{array}$ & 3893.75 & 3462.50 & 3025.00 & 3937.50 & 4981.25 & 3437.50 & 3093.75 & 4498.75 \\
\hline & & Agri nlabourers & 1606.25 & 1781.25 & 1781.25 & 2175.00 & 5531.25 & 1025.00 & 3206.25 & 2112.50 \\
\hline \multirow[t]{2}{*}{2} & \multirow[t]{2}{*}{$\begin{array}{l}\text { Per } \\
\text { animal }\end{array}$} & $\begin{array}{l}\text { Sample } \\
\text { farmers }\end{array}$ & 2307.40 & 2915.78 & 2547.36 & 4846.15 & 2748.27 & 3928.57 & 1980.00 & 4498.75 \\
\hline & & Agri labourers & 2570.00 & 2850.00 & 1900.00 & 2485.71 & 4916.66 & 1822.22 & 4275.00 & 1778.94 \\
\hline
\end{tabular}

( $\mathrm{B}=$ Beneficiaries, $\mathrm{NB}=$ Non Beneficiaries $)$

Table.4 Average annual income of beneficiaries from MGNREGS in Karimnagar and Medak districts (Rs / year)

\begin{tabular}{|l|l|l|l|l|l|l|l|l|}
\hline \multirow{2}{*}{ Particulars } & \multicolumn{4}{|c|}{ Karimnagar } & \multicolumn{3}{c|}{ Medak } \\
\cline { 2 - 10 } & $\begin{array}{l}\text { Income } \\
\text { from } \\
\text { NREGS }\end{array}$ & $\begin{array}{l}\text { Total } \\
\text { income }\end{array}$ & $\begin{array}{l}\text { Income } \\
\text { from } \\
\text { NREGS }\end{array}$ & $\begin{array}{l}\text { Total } \\
\text { income }\end{array}$ & $\begin{array}{l}\text { Income } \\
\text { from } \\
\text { NREGS }\end{array}$ & $\begin{array}{l}\text { Total } \\
\text { income }\end{array}$ & $\begin{array}{l}\text { Income } \\
\text { from } \\
\text { NREGS }\end{array}$ & $\begin{array}{l}\text { Total } \\
\text { income }\end{array}$ \\
\hline $\begin{array}{l}\text { Small } \\
\text { Farmers }\end{array}$ & $\begin{array}{c}14443.62 \\
(25.46)\end{array}$ & 56715.30 & $\begin{array}{l}11793.37 \\
(24.97)\end{array}$ & 47219.27 & 13549.87 & 121400.59 & 12483.0 & 51751.56 \\
$(11.16)$ & & & $(24.12)$ & \\
\hline $\begin{array}{l}\text { Agricultural } \\
\text { Labours }\end{array}$ & $\begin{array}{c}15009.81 \\
(71.83)\end{array}$ & 20893.87 & $\begin{array}{l}12058.87 \\
(50.27)\end{array}$ & 23984.81 & $\begin{array}{l}14826.12 \\
(49.43)\end{array}$ & 29991.18 & 13125.5 & 21189.87 \\
\hline
\end{tabular}

Note: Figures in parenthesis indicates percentage to the total. 
Table.5 Work done pattern by small farmers and agricultural labourers in the study period (number of days in year)

\begin{tabular}{|c|c|c|c|c|c|c|c|c|c|c|}
\hline \multirow{3}{*}{ S.No } & \multirow{3}{*}{\multicolumn{2}{|c|}{ Group }} & \multicolumn{4}{|c|}{ Karimnagar } & \multicolumn{4}{|c|}{ Medak } \\
\hline & & & \multicolumn{2}{|c|}{ HEMs } & \multicolumn{2}{|c|}{ LEMs } & \multicolumn{2}{|c|}{ HEMs } & \multicolumn{2}{|c|}{ LEMs } \\
\hline & & & B & NB & B & NB & B & NB & B & NB \\
\hline \multirow[t]{4}{*}{1} & \multirow[t]{4}{*}{$\begin{array}{l}\text { Small } \\
\text { farmers }\end{array}$} & Farm work & $\begin{array}{l}104.87 \\
(59.82)\end{array}$ & $\begin{array}{c}90.75 \\
(52.81)\end{array}$ & $\begin{array}{l}99.68 \\
(56.58)\end{array}$ & $\begin{array}{l}100.62 \\
(52.05)\end{array}$ & $\begin{array}{l}113.56 \\
(72.50)\end{array}$ & $\begin{array}{c}111.5 \\
(62.11)\end{array}$ & $\begin{array}{c}75.68 \\
(52.17)\end{array}$ & $\begin{array}{c}83.5 \\
(52.06)\end{array}$ \\
\hline & & Non farm work & $\begin{array}{c}40.25 \\
(22.95)\end{array}$ & $\begin{array}{c}48 \\
(27.93)\end{array}$ & $\begin{array}{c}39.93 \\
(22.66)\end{array}$ & $\begin{array}{l}57.37 \\
(29.6)\end{array}$ & $\begin{array}{c}29.37 \\
(18.75)\end{array}$ & $\begin{array}{c}54.62 \\
(33.43)\end{array}$ & $\begin{array}{c}38.62 \\
(26.62)\end{array}$ & $\begin{array}{c}47 \\
(29.30)\end{array}$ \\
\hline & & $\begin{array}{l}\text { Construction } \\
\text { work }\end{array}$ & $\begin{array}{c}30.18 \\
(17.21)\end{array}$ & $\begin{array}{c}33.06 \\
(19.24)\end{array}$ & $\begin{array}{l}36.56 \\
(20.75)\end{array}$ & $\begin{array}{c}35.31 \\
(18.26)\end{array}$ & $\begin{array}{l}13.68 \\
(8.73)\end{array}$ & $\begin{array}{l}13.37 \\
(7.45)\end{array}$ & $\begin{array}{l}30.75 \\
(21.19)\end{array}$ & $\begin{array}{l}29.87 \\
(18.62)\end{array}$ \\
\hline & & Total & $\begin{array}{l}175.31 \\
(100)\end{array}$ & $\begin{array}{c}171.81 \\
(100)\end{array}$ & $\begin{array}{c}176.18 \\
(100)\end{array}$ & $\begin{array}{c}193.31 \\
(100)\end{array}$ & $\begin{array}{l}156.62 \\
(100)\end{array}$ & $\begin{array}{l}179.5 \\
(100)\end{array}$ & $\begin{array}{c}145.06 \\
(100)\end{array}$ & $\begin{array}{c}160.37 \\
(100)\end{array}$ \\
\hline \multirow[t]{4}{*}{2} & \multirow[t]{4}{*}{$\begin{array}{l}\text { Agri } \\
\text { labours }\end{array}$} & Farm work & $\begin{array}{c}61.37 \\
(37.50)\end{array}$ & $\begin{array}{c}69.5 \\
(40.49)\end{array}$ & $\begin{array}{c}76.56 \\
(43.42)\end{array}$ & $\begin{array}{l}53.06 \\
(32.05)\end{array}$ & $\begin{array}{l}101.93 \\
(51.03)\end{array}$ & $\begin{array}{c}59.12 \\
(35.51)\end{array}$ & $\begin{array}{c}80.43 \\
(52.53)\end{array}$ & $\begin{array}{c}56.37 \\
(42.83)\end{array}$ \\
\hline & & Non farm work & $\begin{array}{c}54.25 \\
(33.15)\end{array}$ & $\begin{array}{c}52.31 \\
(30.48)\end{array}$ & $\begin{array}{c}60.81 \\
(34.49)\end{array}$ & $\begin{array}{c}55.37 \\
(33.92)\end{array}$ & $\begin{array}{c}65.68 \\
(32.88)\end{array}$ & $\begin{array}{c}91.87 \\
(55.18)\end{array}$ & $\begin{array}{l}53.68 \\
(35.06)\end{array}$ & $\begin{array}{c}39.43 \\
(29.96)\end{array}$ \\
\hline & & $\begin{array}{l}\text { Construction } \\
\text { work }\end{array}$ & $\begin{array}{c}48 \\
(29.33)\end{array}$ & $\begin{array}{c}49.81 \\
(29.02)\end{array}$ & $\begin{array}{c}38.93 \\
(22.08)\end{array}$ & $\begin{array}{c}54.81 \\
(33.57)\end{array}$ & $\begin{array}{c}32.12 \\
(16.08)\end{array}$ & $\begin{array}{c}15.5 \\
(9.30)\end{array}$ & $\begin{array}{c}19 \\
(12.40)\end{array}$ & $\begin{array}{c}35.81 \\
(27.20)\end{array}$ \\
\hline & & Total & $\begin{array}{l}163.62 \\
(100)\end{array}$ & $\begin{array}{c}171.62 \\
(100)\end{array}$ & $\begin{array}{c}176.31 \\
(100)\end{array}$ & $\begin{array}{c}163.25 \\
(100)\end{array}$ & $\begin{array}{c}199.75 \\
(100)\end{array}$ & $\begin{array}{l}166.5 \\
(100)\end{array}$ & $\begin{array}{c}153.12 \\
(100)\end{array}$ & $\begin{array}{c}131.62 \\
(100)\end{array}$ \\
\hline
\end{tabular}

Note: Figures in parenthesis indicates percentage to the total.

Table.6 Regression analysis for sample farmers

\begin{tabular}{|c|c|c|c|c|c|}
\hline S.No & Area & Regression equation & $\begin{array}{l}\text { Average total } \\
\text { annual } \\
\text { income(In } \square . \text {.) }\end{array}$ & $\begin{array}{c}\mathrm{R}^{2} \\
\text { Value }\end{array}$ & $\begin{array}{l}\text { Standard } \\
\text { Error }\end{array}$ \\
\hline 1 & $\begin{array}{l}\text { Beneficiaries in HEMs } \\
\text { Karimnagar }\end{array}$ & $\begin{array}{l}Y=-23013.4+21.80 X_{1}-1777.8 X_{2}-936.18 X_{3}-1156.99 X_{4} \\
+0.95 X_{5}+39.06 X_{6}+392.73 X_{7}+1.08 X_{8}^{* *}\end{array}$ & 56715.30 & 0.969 & 4510.55 \\
\hline 2 & $\begin{array}{l}\text { Non beneficiaries in } \\
\text { HEMs Karimnagar }\end{array}$ & $\begin{array}{l}\mathrm{Y}=-5780.31-12.84 \mathrm{X}_{1}-3148.95 \mathrm{X}_{2}+1073.33 \mathrm{X}_{3}- \\
3950.98 \mathrm{X}_{4}+0.82 \mathrm{X}_{5}+155.86 \mathrm{X}_{6}+122.48 \mathrm{X}_{7}+0.93 \mathrm{X}_{8} * *\end{array}$ & 62409.73 & 0.986 & 4723.96 \\
\hline 3 & $\begin{array}{l}\text { Beneficiaries in LEMs of } \\
\text { Karimnagar }\end{array}$ & $\begin{array}{l}Y=81369.1-398.36 X_{1}-16603.2 X_{2} *+481.89 X_{3}- \\
6962.58 X_{4}+0.27 X_{5}+49.68 X_{6}-127.32 X_{7}+1.03 X_{8} * *\end{array}$ & 47219.27 & 0.954 & 4895.61 \\
\hline 4 & $\begin{array}{l}\text { Non beneficiaries in } \\
\text { LEMs of Karimnagar }\end{array}$ & $\begin{array}{l}Y=-42509.3+324.25 X_{1}+116.77 X_{2}-2482.52 X_{3}+ \\
1800.2 X_{4}+0.93 X_{5}^{*}+126.7 X_{6}^{*}+171.07 X_{7}+1.11 X_{8}^{* *}\end{array}$ & 48082.64 & 0.977 & 4763.28 \\
\hline 5 & $\begin{array}{l}\text { Beneficiaries in HEMs of } \\
\text { Medak }\end{array}$ & $\begin{array}{l}Y=11334.95+133.21 X_{1}-2647.42 X_{2}+259.79 X_{3}-32.95 X_{4} \\
+1.11 X_{5}^{*}-2.46 X_{6}+26.96 X_{7}+1.00 X_{8}^{* *}\end{array}$ & 121400.59 & 0.999 & 4102.13 \\
\hline 6 & $\begin{array}{l}\text { Non beneficiaries in } \\
\text { HEMs of Medak }\end{array}$ & $\begin{array}{l}Y=-1789.32-37.14 X_{1}+622.85 X_{2}-722.94 X_{3}+1029.1 X_{4} \\
+1.30 X_{5}^{*}+27.72 X_{6}+75.42 X_{7}+0.98 X_{8} * *\end{array}$ & 112850.35 & 0.998 & 4096.53 \\
\hline 7 & $\begin{array}{l}\text { Beneficiaries in LEMs of } \\
\text { Medak }\end{array}$ & $\begin{array}{l}Y=-19030.9+286.93 X_{1}+3334.35 X_{2}+2126.61 X_{3}- \\
2474.89 X_{4}+1.69 X_{5}^{*}+75.26 X_{6}+63.03 X_{7}+1.01 X_{8}^{* *}\end{array}$ & 51751.56 & 0.990 & 4303.46 \\
\hline 8 & $\begin{array}{l}\text { Non beneficiaries in } \\
\text { LEMs of Medak }\end{array}$ & $\begin{array}{l}Y=-51949.9-461.79 X_{1}-9688.03 X_{2}+2796.02 X_{3}+ \\
1417.97 X_{4}-3.52 X_{5}^{* *}+74.26 X_{6}-491.15 X_{7}-0.10 X_{8}\end{array}$ & 18602.68 & 0.917 & 8274.32 \\
\hline
\end{tabular}


Table.7 Regression analysis for sample agricultural labourers

\begin{tabular}{|c|c|c|c|c|c|}
\hline S.No & Area & Regression equation & $\begin{array}{l}\text { Average total } \\
\quad \text { annual } \\
\text { income(In } \square .)\end{array}$ & $\begin{array}{c}\mathrm{R}^{2} \\
\text { Value }\end{array}$ & $\begin{array}{l}\text { Standard } \\
\text { Error }\end{array}$ \\
\hline 1 & $\begin{array}{l}\text { Beneficiaries in } \\
\text { HEMs } \\
\text { Karimnagar }\end{array}$ & $\begin{array}{l}Y=-19634.3-56.62 X_{1}+120.09 X_{2}+991.29 X_{3}+ \\
0.93 X_{4}^{* *}+103.55 X_{5}^{*}+177.78 X_{6}^{* *}\end{array}$ & 20893.87 & 0.929 & 1836.19 \\
\hline 2 & $\begin{array}{l}\text { Non } \\
\text { beneficiaries in } \\
\text { HEMs } \\
\text { Karimnagar }\end{array}$ & $\begin{array}{l}Y=-22609.8-18.64 X_{1}+134.04 X_{2}+2.32 X_{3}+ \\
0.93 X_{4}^{* *}+117.64 X_{5}^{* *}+192.70 X_{6}^{* *}\end{array}$ & 21902.43 & 0.996 & 485.39 \\
\hline 3 & $\begin{array}{l}\text { Beneficiaries in } \\
\text { LEMs of } \\
\text { Karimnagar }\end{array}$ & $\begin{array}{l}Y=-14186.1-95.07 X_{1}-698.31 X_{2}-974.17 X_{3}+ \\
0.96 X_{4}^{* *}+116.28 X_{5}^{* *}+187.01 X_{6}^{* *}\end{array}$ & 23984.81 & 0.956 & 1429.04 \\
\hline 4 & $\begin{array}{l}\text { Non } \\
\text { beneficiaries in } \\
\text { LEMs of } \\
\text { Karimnagar }\end{array}$ & $\begin{array}{l}Y=-19378.5-13.80 X_{1}-126.96 X_{2}+236.1 X_{3}+ \\
1.01 X_{4}^{* *}+121.42 X_{5}^{* *}+158.54 X_{6}^{* *}\end{array}$ & 22400.12 & 0.996 & 449.50 \\
\hline 5 & $\begin{array}{l}\text { Beneficiaries in } \\
\text { HEMs of } \\
\text { Medak }\end{array}$ & $\begin{array}{l}Y=-22753.8-27.54 X_{1}+315.30 X_{2}-49.59 X_{3}+ \\
0.99 X_{4}^{* *}+124.32 X_{5}^{* *}+185.99 X_{6}^{* *}\end{array}$ & 29991.18 & 0.995 & 1127.53 \\
\hline 6 & $\begin{array}{l}\text { Non } \\
\text { beneficiaries in } \\
\text { HEMs of } \\
\text { Medak }\end{array}$ & $\begin{array}{l}Y=48130.23+45.82 X_{1}+2783.88 X_{2}+735 X_{3}+ \\
1.07 X_{4}-50.32 X_{5}-201.57 X_{6} *\end{array}$ & 22367.5 & 0.573 & 3300.48 \\
\hline 7 & $\begin{array}{l}\text { Beneficiaries in } \\
\text { LEMs of } \\
\text { Medak }\end{array}$ & $\begin{array}{l}Y=3319.45-13.24 X_{1}-722.56 X_{2}-539.04 X_{3}+ \\
1.04 X_{4}^{* *}+106.31 X_{5}^{* *}+12.68 X_{6}\end{array}$ & 21189.87 & 0.982 & 1257.91 \\
\hline 8 & $\begin{array}{l}\text { Non } \\
\text { beneficiaries in } \\
\text { LEMs of } \\
\text { Medak }\end{array}$ & $\begin{array}{l}Y=-15906.8-8.93 X_{1}-227.86 X_{2}+39.83 X_{3}+ \\
0.97 X_{4}^{* *}+125.61 X_{5}^{* *}+133.37 X_{6}\end{array}$ & 18602.68 & 0.997 & 326.55 \\
\hline
\end{tabular}

Figure.1 Incomes of the sample farmers on per family basis

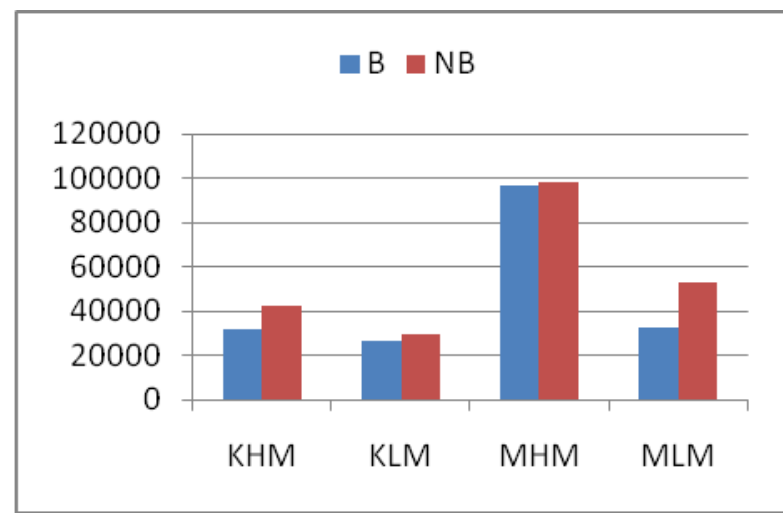

Where, KHM = Karimnagar Highest Expenditure Mandals

KLM = Karimnagar Lowest Expenditure Mandals

MHM = Medak Highest Expenditure Mandals

MLM $=$ Medak Lowest Expenditure Mandals
Figure.2 Incomes of sample farmers on per hectare basis

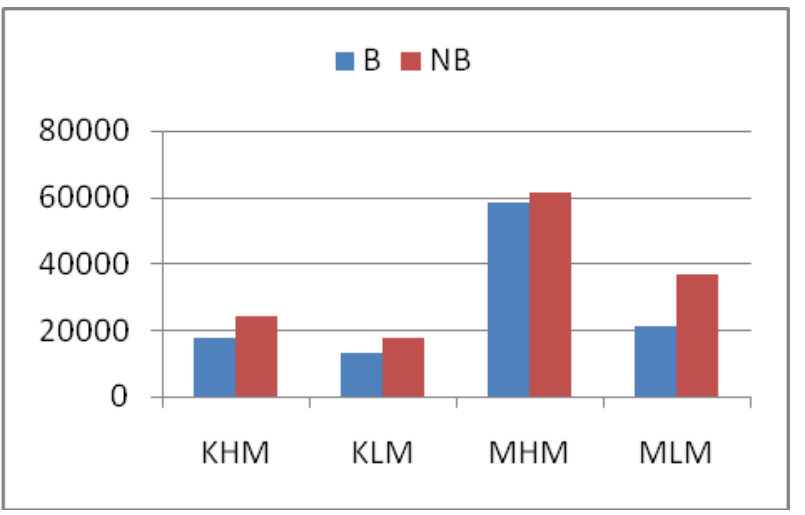


Figure.3 MGNREGS beneficiary farmer's incomes

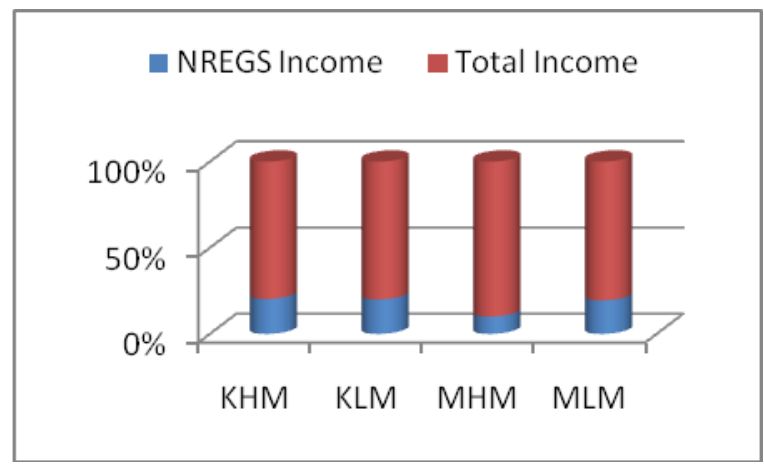

Figure.4 MGNREGS beneficiary labourers incomes

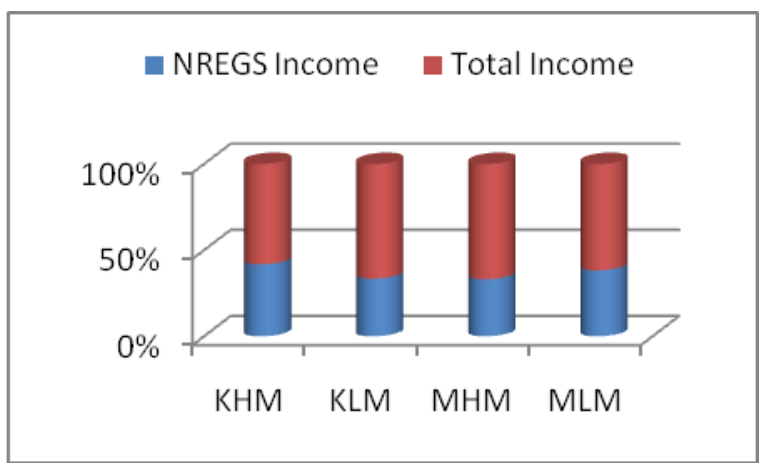

Figure.5 Average total annual income of small farmers

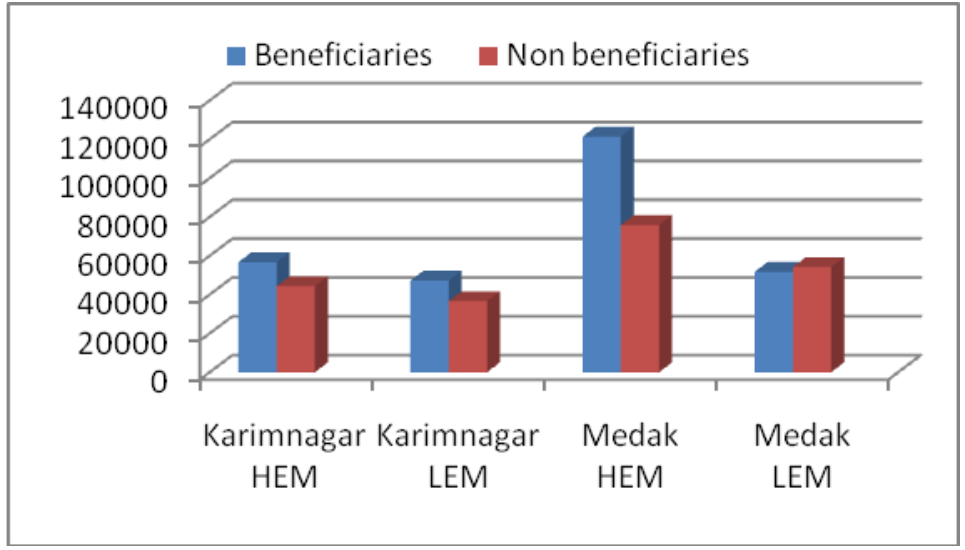

Figure.6 Average total annual incomes of agricultural labourers

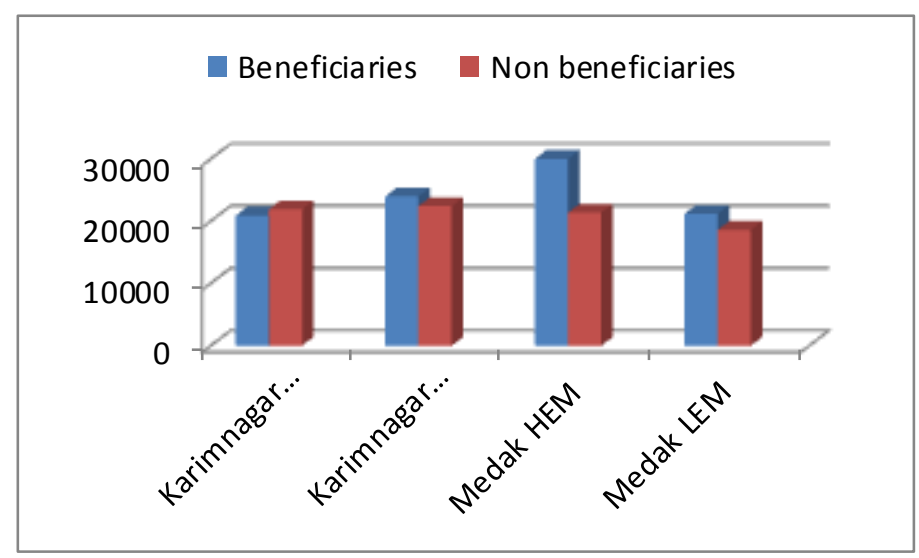


The dependent and independent variables considered in case of farmers were

$\mathrm{Y}=$ Total annual income,

$\mathrm{X}_{1}=$ Age,

$\mathrm{X}_{2}=$ Education,

$\mathrm{X}_{3}=$ Land holding,

$\mathrm{X}_{4}=$ Family size,

$\mathrm{X}_{5}=$ Income from live stock,

$\mathrm{X}_{6}=$ Total number of employment days,

$\mathrm{X}_{7}=$ Average wage rate,

$\mathrm{X}_{8}=$ Income from agriculture,

* Significant at $5 \%$ level

** Significant at $1 \%$ level

To know the factors affecting the total annual incomes, the following equations were fitted (Table 6) and found that income from agriculture is the variable found significant at $1 \%$ and $5 \%$ in all the cases and the standard error varied between 4096.53 and 8274.32

\section{ii) Agricultural labourers}

To study the influence of various factors effecting on total annual incomes of beneficiary and non beneficiary labourers of highest and lowest expenditure mandals of Karimnagar and Medak districts, multiple regression analysis was carried out after confirming that there was no multicolinearity among the identified variables.

The dependent and independent variables considered in case of labourers were

$\mathrm{Y}=$ Total annual income,

$\mathrm{X}_{1}=$ Age,

$\mathrm{X}_{2}=$ Education,

$\mathrm{X}_{3}=$ Family size,

$\mathrm{X}_{4}=$ Income from livestock,

$\mathrm{X}_{5}=$ Total number of employment days,

$\mathrm{X}_{6}=$ Average wage rate.

* Significant at $5 \%$ level

** Significant at $1 \%$ level

To know the factors affecting the total annual incomes, the following equations were fitted (Table 7) and found that income from livestock, total number of employment days, average wage rate was the variables found significant at $1 \%$ and $5 \%$ in majority of the cases and the standard error varied between 326.55 and 3300.48 .

Summery and conclusion of the studies are as followed

\section{Impact of MGNREGS on income pattern}

Per farm income of beneficiary group farmers in highest expenditure mandals of Karimnagar was $\square 42120$ while in Medak the non beneficiary group farmers in highest expenditure mandals was - 98431. The agricultural labourers livestock income among non beneficiary group was -2175 in Karimnagar while in Medak, among beneficiary group, the highest expenditure mandals realized -5531 . Though there was no statistically significant difference between beneficiaries and non beneficiaries in income, but in all the cases an absolute difference was observed.

\section{Impact of MGNREGS on employment pattern}

Beneficiary farmers in HEMs of Karimnagar got 175.31 days of total work while non beneficiary farmers got 171.81 days. Beneficiary farmers in LEMs of Karimnagar got a total of 176.18 days and non beneficiaries got 193.31 days. In Medak, beneficiary farmers in HEMs got 156.62 days of total work and 179.5 days in case of non beneficiaries. In LEMs, beneficiary farmers got 146.06 days and non beneficiaries got 160.37 days. Here also, though there was no statistically significant difference between beneficiaries and non beneficiaries in employment days, but in all the cases an absolute difference was observed. 


\section{Income mobility among beneficiaries}

Income transition was clearly seen in case of farmers and agricultural labourers due to MGNREGS income and majority of farmer's income ranges were higher than agricultural labourers. Majority of labourers crossed poverty line in HEMs of Karimnagar with the help of income from MGNREGS.

\section{Linear regression analysis}

Major discriminator between beneficiary and non beneficiary farmers were total annual income (172.43\%), expenditure on hired human labour (80.59\%), income from livestock (7.29\%) and age of labourer (4.8\%). Major discriminating factors between beneficiary and non beneficiary agricultural labourers were total annual income (50.70\%), social class $(45.15 \%)$, total employment days (37.24\%), family size $(32.63 \%)$ and average wage rate $(11.84 \%)$. In case of linear regression analysis, the identified independent variables explained about 97.37 per cent and 92.8 per cent variation in total annual incomes of farmers and labourers respectively. Income from agriculture and income from livestock found to be significant in case of farmers and in case of labourers, the total employment days and average wage rate were found significant.

\section{References}

Ahuja, U. R., Tyagi, D., Chauhan, S. and Chaudhary, K.R. 2011. Impact of MGNREGA on rural employment and migration: a study in agriculturally backward and agriculturally advanced districts of Haryana. Agricultural Economics Research Review. 24 (Conference number):495-502.

Akthar, S.M.J and Azeez, N.P.A. 2012. Budgetary allocation and its utilization
MGNREGS- a view point. Kurukshetra. 60(6):19-22.

Akthar, Y. 2009. NREGA - case study. Kurukshetra. 58(1):20.

Alha, A and Yonzon, B. 2011. Recent development in farm labour availability in India and reasons behind its short supply. Agricultural Economics Research Review. 24(Conference number):381-390.

Basavaraj, G. 2011. Impact and implications of MGNREGA on labour supply and income generation for agriculture in central dry zone of Karnataka. Agricultural Economics Research Review. 24 (Conference number):485494.

Divakar Reddy, P., Vijay Kumar, N., Dinesh, T.M. and Shruthi, K. 2016. Impact of MGNREGA on income, expenditure, savings pattern of beneficiaries in North-Eastern Karnataka. Economic Affairs 61(1):101-106.

Jha, R.R. 2011. Impact of MGNREGA on wage employment and income generation: a case study of Darbhanga district in Bihar. Agricultural Economics Research Review. 24(Conference number):557.

Kumar, T and Vora, Y. 2012. Reforms under MGNREGS in Rajasthan. Yojana. 56(11):31-34.

Pattanaik, B.K and Lal, H. 2011. Mahatma Gandhi NREGA and social audit system of village panchayats. Kurukshetra. 59(3):23-25.

Sarkar, P., Kumar, J and Supriya. 2011. Impact of MGNREGA on reducing rural poverty and improving socioeconomic status of rural poor: a study in Burdwan district of West Bengal. Agricultural Economics Research Review. 24(Conference number):437-448 .

Srivastava, N and Srivasatava, R. 2010. Women, Work and Employment 
outcomes in Rural India. Economic and Political Weekly. 45(28):49-60.

Thadathil, M.S. and Mohandas, V. 2011. Impact of MGNREGS on labour supply in the agricultural sector of
Wayanad district, Kerala. Agricultural Economics Research Review. 24 (Conference number):560.

\section{How to cite this article:}

Kumara Swamy, D., C.V. Hanumanthaiah, P. Parthasarathy Rao, K. Suhasini and Narendranath, V.V. 2018. Impact of 'Mgnregs' on Income and Employment of Small Farmers and Labourers: A Comparative Study in Telangana State. Int.J.Curr.Microbiol.App.Sci. 7(07): 2236-2248. doi: https://doi.org/10.20546/ijcmas.2018.707.262 